Indonesian Journal of EFL and Linguistics

Vol. 5 No. 1, 2020

eISSN: 2503-4197, pISSN: 2527-5070

www. indonesian-efl-journal.org

\title{
Perlocutionary Act of Euphemism in Indonesian Presidential Election Debate 2019
}

\author{
Wahyuningsih \\ Magister Linguistik, Universitas Diponegoro Semarang, Indonesia \\ e-mail: ayunope@gmail.com \\ Deli Nirmala \\ Universitas Diponegoro Semarang, Indonesia \\ e-mail: deliundip@gmail.com
}

\begin{abstract}
:
Presidential election debate attracts public attention toward general election. Through the presidential debate, euphemism is uttered by candidates, and it creates effect to other debaters. This paper is focused on examining effect (perlocutionary act)of euphemism in presidential election debate 2019. The corpus covers the utterances containing euphemism and their responses as the effect produced by the candidates in the prime presidential election debate 2019. The methods used in analyzing data were pragmatics identity method and referential method. The results show that the effect of using euphemism includes verbal perlocutionary act acceptance namely agreement and verbal perlocutionary act refusal includes contradiction, rebuttal, disagreement, denial and criticism. Verbal perlocutionary act acceptance is only expressed by a candidate from the same party as support. However, the verbal perlocutionary act of refusal is expressed by candidates respectively. It indicates that each candidate has different ideology and communication strategy.
\end{abstract}

Keywords: debate, euphemism, Perlocutionary Act 


\section{INTRODUCTION}

Speech events occur in both daily communication and other activities, which produce speech. According to Austin (1962) in producing speeches, a person does not only state a word but also takes an action. It means that when someone says something, he or she has an intention called speech act. Speech act has a series of speech events that emphasize at the meaning of actions in the speech. Speech acts and speech events are two aspects that exist in one process, namely communication process (Chaer, 1995:65). From this point of view, the speech event occurs at a certain place, time, and situation. Speech situation is a situation where the speech takes place. This point out that speech is an effect, while the situation of speech is the cause. In a speech, it is not always a direct representing meaning but there are various purposes that can be expressed by a speech, or vice versa. As in debates, the candidates producing speeches do not only say the words but also have a purpose of action that refers to speech acts.

Many researchers have conducted the studies of a speech act in debate, for instance Juwita (2017) conducting the study on the speech act in the 2014 Indonesian presidential debates and Andrasari (2016) analyzing commissive speech acts in Sambas district election debate in 2015. Other articles related to research on debate have also been written by Agustina \& Bahrani (2016). They examined the practice of debate by students in implementing British parliamentary debates on the debate system. In addition, Citraresmana (2019) has studied the image scheme in the concept of meaning 'our' and ' $u s$ ' in the 2019 Indonesian presidential debate.

Like the other studies mentioned previously, this current research deals with the presidential election debate, since the debate has become a popular phenomenon, as one of the biggest political parties in Indonesia, Democratic Party, voted to the President for the next five years. The elected candidate will decide the policies and programs in the state so that he may influence the government policies that may affect the public. From this perspective, the phenomenon of language usage in debate is an interesting to study.

The purpose of the presidential debate is as the same as political campaigns, that is, to find supporters and to let the public know the vision, mission, and programs. Through debate, candidates have the opportunity to present their programs and provide ideas and arguments in front of audiences. As Indarwati (2019) states in political campaigns, each candidate competes with variety of ways and strategies to persuade audiences to be their voter. Hence, to catch the voter's opinion, candidates use various communication strategies in competing arguments to reinforce their ideologies and notion.

Debate is an activity of exchanging ideas between two or more people whose aim is to influence others to accept notion by the speaker (Wiyanto, 2003). To achieve the goal, the speakers use language that can affect each other because each speech may have an effect on the debate opponent and it may affect their social self-image topublic. The debate participants will consider the language they used to strengthen ideology or 
attack opponents without violating language ethics or appearing rude, therefore the debate candidates tend to use euphemism.

Euphemism is a communication strategy to express the same intentions. However, it uses different expressions and is considered more polite in general. Speakers use euphemisms in general for a purpose to soften the utterances that may function as politeness strategies. Prayitno (2019) argues, Politeness is a communication strategy using language that is polite and cultured. As in debates, the use of euphemism as an alternative way to argue and attack the opponents in a subtle way without violating communication ethics.

The study of euphemism was appealing interest by some researchers so far. This linguistic device was appropriate applied in various language studies and fields. Some researchers have studied euphemism broadly. For instance, the study of euphemism in the printed media such as article written by Sulistyono (2016) focusing on the use of euphemisms in obituary newspapers by classifying the structure of euphemisms and their functions based on the context. Other research was studied by Samoškaitè (2011). He examines the euphemism in the political sphere in the printed media The Guardian. He investigated the approach related to the concepts, features of euphemisms, and identified political euphemisms used in English newspapers. However, Fernandez (2014) examines how euphemisms used by political actors to save face on unpleasant issues and tools to criticize opponents without showing negative impressions in front of audiences. In addition, the study of euphemism in social media conducted by Astuti (2016) that examines the form of euphemism and its function in Facebook account comments. Furthermore, Arif (2015) in her publication, the purpose is to identify the main function of euphemism in modern society. Her analysis shows that euphemism is a tool leading politics for persuasive purposes rather than only as a form of politeness.

The previous studies outlined above are focused on the analysis of speech acts in debate and euphemism in media. Meanwhile, the researchers have looked that in debate, the use of euphemism by a candidate has raised an effect to other debaters. As speech event in general, every utterance produced by someone often has a power of influence or an effect to the listeners or interlocutors. The effect may vary such as feeling anxiety, pleasure or expressing something. The effect of the speech is called perlocutionary act. Perlocutionary act is caused by previous speech that is a response of intended meanings of the speaker. Thus, the study on the perlocutionary act is intrinsically one sequence of the speech act. Such as article written by Fitriani (2017) who studied speech act in the novel, she found perlocutionary such as apology, admiration and prohibition. Nadeak, Sunggingwati, and Valiantien (2016) studied on illocutionary act in the movie. While Insani \& Sabardila (2016) examined perlocutionary speech acts of Indonesian language between teachers and students. The results show that the expressive speech acts produced by students are hatred, pleasure, excitement. 
It seems that there are only a few studies focusing on perlocutionary act in political realm especially on Presidential debates, even there is not any article investigating perlocutionary act in the Presidential debates in Indonesian general election 2019. Therefore, examining exclusively the perlocutionary act in political sphere can be useful to add insight into linguistic devices realized in political sphere. The difference between the current study and the previous one lies on the effect of using euphemism that had not studied before. If the previous studies focused on speech acts, debate and euphemisms are analyzed separately, this study will consider integrating them in one analysis. Hence, this study tries to analyze the effect of using euphemism in 2019 Indonesian presidential debate. Authors will apply theory of debate, speech acts theory particularly perlocutionary acts and euphemism.

\section{LITERATURE REVIEW}

\subsection{Euphemism}

Euphemism is the same expression to say speech as a substitute for words considered offensive. Euphemism can act as an alternative way to replace words that are taboo or unpleasant for those who hear (Allan \& Burridge, 1991). Euphemism plays a role giving choice of taboo or what is considered rude, thus, speakers try to lower the tone and disguise the meaning of utterances for the purpose being polite (Burridge, 2012). Thus, in communication, using polite language is more favorable than vivid or clear statements. On the other hand, euphemism is a part of linguistic tool that acts indirectly as a verbal strategy because indirect speech gives a higher choice to the listener and minimizes their rude statements (Leech, 1983).

Euphemism can hide seemingly straightforward words behind deceptive or overly complex ones (Lacone, 2003). In politics, euphemism acts as tools of hegemony, persuasion, and even attacks the opponents subtly. As pointed by Burridge \& Allan (2003) which refers to "deceptive euphemism" that is language sounding polite tends to be manipulated. This type of euphemism is generally used in the realm of politics such as in political debates. Candidates try to convince the public regarding their vision and mission by using soft, polite and politically correct words. The use of euphemism seems to be polite in debate although it has a negative meaning.

In political debate, candidates appeal to avoid the direct statement to say crude words or unpleasant things that may threat their social public image, indeed they consider using euphemism strategy for they want to sound polite and tactful and sometimes more official to gain audience's attention. Euphemism is a sign of politeness as a behavior to mitigate conflict and ensure mutual protection for both speakers and listeners (Brown, 1987).

\subsection{Perlocutionary Acts}

Austin (1962) introduces three types of speech acts that can be realized by the speaker, namely locution, illocution and perlocution. Those three acts are occurred in the same speech context. The first is locutionary act; it is the act of producing words or stating 
something. Locutionary act such an act that is only saying something like giving information, asking, and so on (Austin, 1962). The second is illocutionary act that is act of doing something based on what said. Illocutionary act is, therefore, what is achieved by saying something; it is not just description but also rather an act that requires intention to the speech partner to do something. It is often called performance of an act in saying something (Austin, 1962). In the speech acts theory, the term illocution refers to the use utterances to express manner by the function or certain power illocution. By other words 'power illocutionary' is the speaker's intention. The expression of illocutionary acts like assertion, request, promise, apology and so forth. The third is perlocutionary act, which is the effect of the speech (locution) which contains certain intentions (illocution) then the effect is (perlocution). Perlocutionary act is called the 'effect of speech', that is an act carried out by listeners influenced by the speaker. On the speech event, generally, a speech act has potential effect or power of influence (perlocutionary force) toward interlocutors or listeners.

According to Austin (1962), the perlocutionary act, is 'what the result of saying something', such as convincing, persuading, hindering, and saying something that possible to give raise an effect to interlocutors. Perlocutionary act is thus a relationship of cause-effect between two events, the cause is the speech produced by the speaker, and the effect is a reaction by interlocutors who are involved. Saifudin (2019) stated the perlocutionary act seemed natural language phenomenon, which is not regulated by convention and cannot be confirmed. What the speaker says have an effect that may affect the feelings or thoughts of the interlocutors or people involved in the situation. The effect may vary both verbal and non-verbal acts. The verbal acts for instance; saying agrees or disagrees, arguing, refusing, and expressing something and so on. The analysis of perlocutionary acts focused on the effect of speech, thus it emphasis on the interlocutors influenced by illocutionary act of the speaker.

Speech acts theory proposed by Austin and then developed by Searle (1969) are particularly categories of illocutionary acts. However, Searle in (Fitriani, 2017 :53) has classified perlocutionary acts into three types. They are; (1) verbal perlocutionary acts, that is responses shown by the interlocutors orally. It can be expression of acceptance or rejection of the speaker's intention, for instance the expressions like denying, prohibiting, saying thank you, apologize, and so on. (2) Non-verbal perlocutionary acts, it is the responses shown by the interlocutor in the form of sign or movements such as nodding, shaking his head, laughing, smiling, and so on. (3) Verbal-nonverbal acts; it is the responses shown by the interlocutor in the form ofverbal speech accompanied by movements (nonverbal), for instance talking while laughing or an action requested by the interlocutor.

\subsection{Indonesian Presidential Debate}

According to Dipodjojo (1982:59) debate is a process of oral communication expressed in language to maintain a notion. Each party asserts an argument on debate, provides opinion in a certain way so that the opposing party or other party who listens 
to debate becomes convinced takes side on him. He reveals that debate is a part of language skills related to politeness. Polite in using language is one of the skills in preserving language (Dipodjojo, 1982:59). Primarily, a debate has aimed to find solutions to problems debated. Another goal is to achieve glory over arguments in finding supporters to occupy high positions such as the President. Debate, in general, involves language as speech act that includes the speaker's purpose in producing utterances and the effect to the opponent. Words choice used in debate might be diverse; it depends on the context and culture.

Debate culture in Indonesia is different from Western debates such as America even though Indonesian debate adopts the American debate system. In the implementation of US, presidential election debates tend to use straightforward language and directly to criticize the opponents. Indonesian presidential debate, otherwise, if speakers use vivid language, they will be considered impolite because the levels of face threatening acts are high or it may be offensive. It indicated that politeness culture in communication truly applied in Indonesia. Therefore, polite languages like euphemism discovered in Presidential debate.

Presidential election debate in Indonesia is a series of debate events that held in the event towards general election. In the 2019 presidential election debate, the participants were a pair of the incumbent President Joko Widodo with vice-presidential candidate Ma'ruf Amin versus presidential candidate PrabowoSubiyanto with vicepresidential candidate Sandiaga Uno. The debate led by a moderator that manages the turns taking when debate took place. Debate series consists of five segments, each segment consisting of six rounds. The debate has taken place on January 17, 2019 April 13, 2019. The topics in the debate include social issues and governance fields such as Law and Human Rights, Corruption, Terrorism, Ideology, Government and so on.

\section{RESEARCH METODHOLOGY}

This research is qualitative research that is based on the phenomenon considered on the context and described in the form of words or sentences. Qualitative analysis focused on the meaning by describing language illustrated in the form of words or sentences rather than numbers or figures (Mahsun, 2007 : 233).

Authors employ descriptive method to comprehend language phenomena in the 2019 presidential election debate. According to Sudaryanto (1993), descriptive methods are research methods based on purely facts of existing language or empirical phenomena. The descriptive method aims to describe systematically, factually and accurately about the facts and its relations among the phenomena investigated. In this study, authors identified and analyzed the effects of euphemisms from the data obtained factually.

The data provided were utterances in the form of either word or phrases indicated as a type of euphemism. The data analyzed were utterances that are the responses as the effects of using euphemisms produced by candidates in presidential debate 2019. The 
participants were incumbent President Joko Widodo, presidential candidate Prabowo Subiyanto and vice president candidate Sandiaga Uno. The data source was a visual recording of the 2019 presidential election debate supported by transcription. The series of debates used as sample is the prime presidential debate of second round, which consists of three segments with the topics of Law and Human right.

The techniques of collecting data were done by (1) observation method; observation is done by observing the language use (Sudaryanto, 1993). The researcherswatched and observed the visual recording of the 2019 presidential election debate. The researchers used the basic techniques of tapping/recording and several extension techniques, which include non-participant observation technique (teknik simak bebas libat cakap), in this technique, researchers did not participate in the discussion when observing the data (Sudaryanto, 1993). Researchers only pay attention and listen to what was said by the speakers in the data source. (2) Documentation technique, the researchers downloaded the documentation of the visual recording of the 2019 presidential debate from Youtube. (3) The note-taking technique, the researchers made transcriptions in the sentence form.

When the transcription was available in the text form, the researchers conducted data analysis by the following methods; (1) Referential identity method (metode padan referensial) was used to identify the referent referring to euphemistic expression that is used as the basis to analyze the perlocutionary act. (2) The pragmatic identity method (metode padan pragmatis), researchers analyzed the effect of speech which is a response based on the utterances produced by the previous speaker containing the euphemism.

\section{FINDINGS}

This section shows the finding based on the data analysis. The analysis focused on the effect of using euphemism in Presidential debate 2019. The candidates involved are Joko Widodo (JW), Prabowo Subiyanto (PS) and Sandiaga Uno (SU). Each candidate gained the same opportunity in delivering arguments, and turn taking managed by a moderator. Based on the data analysis, the effects (perlocutionary acts) of euphemism produced by candidates respectively will be presented in the following pages. The findings of perlocutionary acts are distributed in the table 1 below:

Table 1: Perlocutionary Acts of euphemism

\begin{tabular}{clc}
\hline Types of perlocutionary acts & \multicolumn{1}{c}{ Expressions } & Speakers \\
\hline Agreement & $\begin{array}{l}\text { It still remains many problems } \\
\text { It is hard to obtain job opportunities } \\
\text { It is difficult to do }\end{array}$ & SU \\
\hline Contradiction & $\begin{array}{l}\text { We are different from Pak Prabowo } \\
\text { We will simplify everything } \\
\text { It is very important }\end{array}$ & JW \\
\hline Rebuttal & $\begin{array}{l}\text { IfI do not see the difference } \\
\text { We want acceleration }\end{array}$ & PS \\
\hline Criticism & Authority is biased & PS \\
\hline Indonesian Journal of EFL and Linguistics, 5(1), 2020 & 119
\end{tabular}


Wahyuningsih \& Deli Nirmala

\begin{tabular}{clc}
\hline & This also is an unfair act & \\
\hline Disapproval & $\begin{array}{l}\text { It is a human rights violation } \\
\text { Your supporters might be } \text { overacting }\end{array}$ & PS \\
\hline Disagreement & $\begin{array}{l}\text { It was } \text { not only an equality } \\
\text { but also access to get opportunity }\end{array}$ & SU \\
\hline Denial & Do not accuse like that Pak Prabowo & JW
\end{tabular}

Table 1 shows the expressions of the effect (perlocutionary acts) produced by candidates in debate. Turn taking and response have been determined, therefore, the analysis of the perlocutionary act focused on the second speaker or interlocutors that respond from the previous speech. The context analysis is each candidate delivering argument and giving response to the issues questioned by the moderator. The result is illustrated in the following chart and then it followed by analysis based on the speech context.

Figure 1

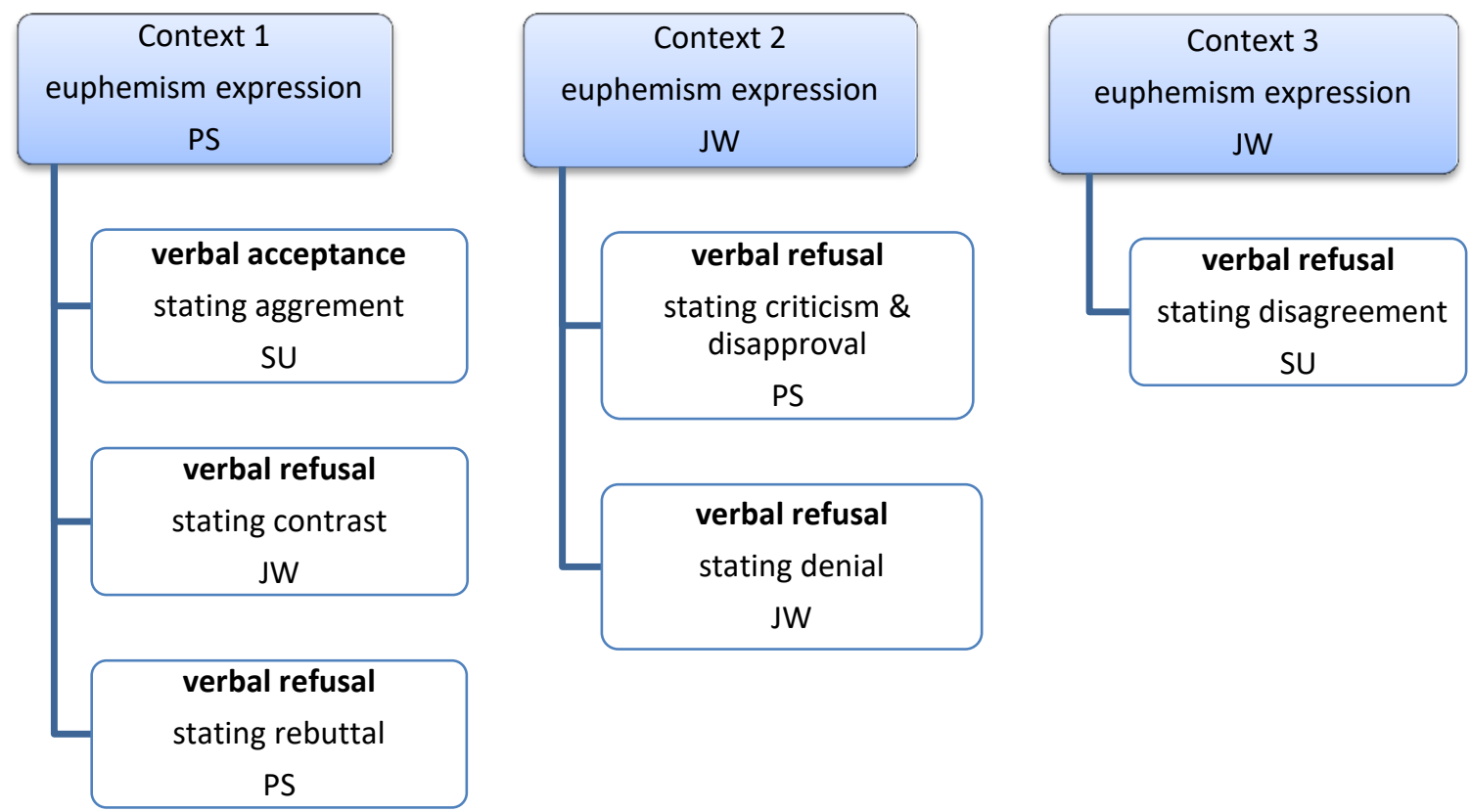

\section{Context 1}

Candidates respond to statement formulated by the moderator related to the overlapping law problem currently. This context consists of a sequence of turn taking from data as follows: 


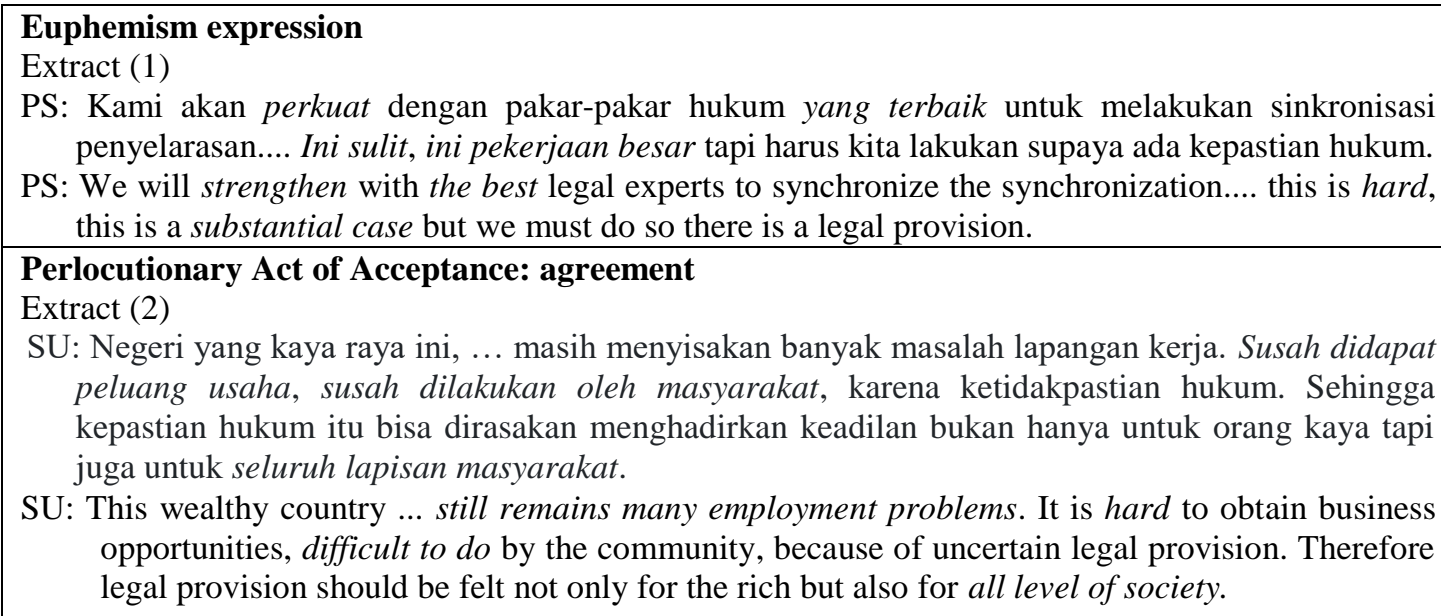

PS: Kami akan perkuat dengan pakar-pakar hukum yang terbaik untuk melakukan sinkronisasi penyelarasan.... Ini sulit, ini pekerjaan besar tapi harus kita lakukan supaya ada kepastian hukum.

PS: We will strengthen with the best legal experts to synchronize the synchronization.... this is hard, this is a substantial case but we must do so there is a legal provision.

\section{Perlocutionary Act of Acceptance: agreement}

Extract (2)

SU: Negeri yang kaya raya ini, ... masih menyisakan banyak masalah lapangan kerja. Susah didapat peluang usaha, susah dilakukan oleh masyarakat, karena ketidakpastian hukum. Sehingga kepastian hukum itu bisa dirasakan menghadirkan keadilan bukan hanya untuk orang kaya tapi juga untuk seluruh lapisan masyarakat.

SU: This wealthy country ... still remains many employment problems. It is hard to obtain business opportunities, difficult to do by the community, because of uncertain legal provision. Therefore legal provision should be felt not only for the rich but also for all level of society.

\section{Perlocutionary Act of refusal: contradiction}

Extract (3)

JW: Kami berbeda dengan Pak Prabowo dan Pak Sandi; penting sekali harmonisasi regulasi kita .... kita akan sederhanakan semиanya sehingga apabila ada tumpang tindih langsung kelihatan dan bisa kita lakukan revisi dengan baik.

JW: We are differentf rom Pak Prabowo and Pak Sandi; it is very important toward harmonization of our regulations, we will simplify everything so that if there is an overlapping it is immediately visible. Therefore, if there is an overlapping ... we can do a good revision.

\section{Perlocutionary Act of refusal: rebuttal}

Extract (4)

PS: Baik terima kasih kalau saya kok tidak lihat perbedaan,... Kita ingin percepatan, selalu urusan di Indonesia masalah terbanyak, masalah terbesar kita ingin terobosan... itu jawaban saya.

PS: Fine, thank you, if I do not see the difference .... We want acceleration; the problem in Indonesia, always the most problem, the biggest problem that we want is a solution that is my answer.

Extract (1) contains euphemism stated by PS such as in the expressions 'strengthen, the best, hard and substantial'. Those expressions refer to the meaning that is not clear and seems to exaggerate the speech intended to disguise uncertain things. In addition, the statement illustrates the legal provision in the country does not work well so that he thought as a substantial case that difficult to resolve.

Extract (2) includes the perlocutionary act of agreement stated by SU. He states there are still many employment problems and it is difficult, hard to obtain business opportunities in the current government. SU's argument in line with PS's statement considering to legal provision in current government considered difficult and substantial case in Indonesia.This statement pointed out that SU has agreed to PS's statement that illustrating poor condition in the society for he thought legal provision is not balance.

Extract (3) includes the perlocutionary act of contradiction stated by JW as response from debate opponent's statement previously. JW states different argument by saying 
the idea in contrast with the opponent. JW resists obviously by stating contraryto expression "we are different from Pak Prabowo and Pak Sandi". His statement and then followed by saying "we willsimplify everything" referring to legal provision case. However, it is seen clearly that JW had contrast idea to PS and SU. Besides by saying "the difference", PS and SU use overstating expression whereas JW rather uses understating expression.

Extract (4) shows perlocutionary act of rebuttal stated by PS. PS argues to JW's statement by expressing "if I do not seethe difference". This indicates objectionby emphasis negation "do not" referring to expression when JW stating "the differences", PS had different opinion that he wants acceleration for he thought there are problems in Indonesia.

\section{Context 2}

Candidates respond to statements about the law enforcement and the issue of human rights. In this context, JW gets the first turn and it affecting PS gives response. The analysis is shown in the following data:

\section{Euphemism Expression \\ Extract (5) \\ JW: Penindakan hukum yang sesuai dengan prosedur itu pelanggaran HAM. Misalnya penahanan terhadap tersangka, memang itu merampas kemerdekaan seseorang tapi penegakan hukum itu melindungi masyarakat. \\ JW: Law enforcement in accordance with the procedure is a violation of human rights. For example restriction to suspected person, indeed that seizes someone's freedom, however law enforcement protects the community.}

\section{Perlocutionary Act of refusal: criticism}

Extract (6)

PS: saya Ingin bertanya bahwa bapak kan sudah memerintah selama 4 tahun lebih. Yang kita ketemukan ada perasaan di masyarakat, bahwa kadang-kadang aparat itu berat sebelah.

PS: I want to ask that you have already led the government about four years ... what we found that there is a sense in the community that sometimes the authority is biased.

\section{Perlocutionary Act of refusal: disapproval}

Extract (7)

PS: Jadi saya kira, ini juga suatu perlakuan tidak adil ya, juga menurut saya pelanggaran HAM ... Saya kira ini yang kami mohon Bapak perhitungkan, mungkin juga ada anak buah Bapak yang mungkin berlebihan.

PS: So I think, this is an unfair act, also in my opinion human rights violations ... I think this what I was beg you to consider, maybe there are also your supporters that might be overacting.

\section{Perlocutionary Act of refusal: denial}

Extract (8)

JW: Jangan menuduh seperti itu Pak Prabowo. Karena kita ini adalah negara hukum, ada prosedur hukum, ada mekanisme hukum yang bisa kita lakukan. Kalau ada bukti, sampaikan aja penegak hukum.

JW: do not accuse like that Pak Prabowo. Because our country is juristical state, there is law procedure, there is mechanism of law that we can do. If there is a proof, report it to the authority. 
Extract (5) shows euphemism expression stated by JW in the expression "seizes someone's freedom". It refers to the taboo meaning of forcefully taking someone's freedom because the word "force" has abusive meaning. This euphemistic expression as an alternative to softenmeanings, which analogized that "freedom" is something abstract conceptualized like a concrete object so that the actual meaning does not seem real.

Extract (6) includes the perlocutionary act of criticism stated by PS. PS responds to JW formulated by figurative language intended to criticize JW's statement about government policy regarding Human right violation. The expression the "authority is biased" may replace taboo meaning of "unfair". PS criticizes the authority under JW's government that considered unfair to the society.

Extract (7) considers the perlocutionary act of disapproval stated by PS.PS expresses his argument by stating "unfairly" referring to violation of human right that he thought JW's supporters dida violation of human right. PS blames the condition in the society in order to JW to be considering to the case.

Extract (8) indicates the perlocutionary act of denial argued by JW. JW responds to PS's statement showed by restricted statement "do not" it means he disproves to what PS said previously that if there is human right violation, it can be reported and JW asserts to PS not to accuse.

\section{Context 3}

Candidates argue their argument to respond statements about people with disabilities who are still often having discrimination, related to the welfare of public facilities, as well as political rights. In this segment, JW is the first speaker and it affects to SU giving response.

\section{Euphemism Expression}

Extract (9)

JW: Setelah keluar Undang-Undang mengenai penyandang disabilitas di tahun 2016, saya melihat bahwa paradigma terhadap kaum disabilitas disini sudah berubah.

JW: After coming up the Law to persons with disabilities in 2016, I see that the paradigm towards persons with disabilities here has changed.

\section{Perlocutionary Act of refusal : disagreement}

Extract (10)

SU: Tadi bukan hanya kesetaraan akses infrastruktur atau akses terhadap pendidikan dan kesehatan tapi juga akses untuk bisa maju mendapat peluang untuk membuka lapangan pekerjaan ... kita akan memastikan putra-putri terbaik bangsa yang difabel, hidup untuk memenuhi potensinya.

SU :... that was not only equality access infrastructure or access education and health, but also access to get opportunity to provide carrier opportunity .... we will ensure the best generation of the nation with disabilities, life to fulfill their potencies. 
Extract (9) considers to euphemism expressionin the word "disability". Disability refers to taboo meaning of "defective" or "cacat" (Indonesian language). In Indonesia, term of person with disability or 'penyandang cacat' is heard being offensive to disabilities community therefore when speaker states in English words, it can substitute taboo meaning and avoid saying impolite way.

Extract (10) includes the perlocutionary act of disagreement stated by SU responding JW's statement regarding the case of people with disability. The statement of "not only ... but also" shows dispute statement, in which SU argues that what JW said about disabilities people that were able to use the facilities such as infrastructure are not quite enough for their prosperity. SU enhances the arguments that he will provide the carrier opportunity so that it shows disagreement toward JW's statement.

\section{DISCUSSION}

In the present paper, authors conduct the analysis according to the objective of the study that is to describe the effects (perlocutionary act) of euphemisms in presidential election debate 2019. What the effect means in this study is seen from collaboration between speakers and interlocutors in the presidential debate context. Based on the analysis, when a candidate of the first speaker mainly used euphemisms stating his argument, he affected the interlocutors to respond by verbal statement both acceptance and rebuttal. The response from interlocutors determines the perlocutionary act.

The results of this study show perlocutionary acts found in the data i.e. statement of agreement, contradiction, disagreement, criticism, rebuttal, and denial. In context 1, a candidate who is the same party states perlocutionary act of verbal acceptance by statement of agreement regarding legal provision that PS thinks does not have right decision. SU agrees by stating that is difficult for society to obtain a business opportunity. Moreover, the perlocutionary act of refusal found is statement of contradiction and disagreement. The contradictory statement is expressed by JW as opponent. JW had different argument to manage legal provision that he had different ways to overcome this case. This contrary idea affects PS as debate opponent responding by disagree statement that he does not consider to any differences but he wants a solution.

In the context 2, however, JW expressed his idea containing euphemism. JW's statement then has affected PS to respond. The perlocutionary act expressed by PS indicates refusal statement by criticism. PS sates what he saw in the society that authority was unjust. This argument tends having meaning to criticize JW's regime is considering unfair. However, it affects JW, he states denial to what PS said that JW argues if there is human right violation in society. Furthermore, in the context 3 , JW expressed his idea containing euphemism and it has affected SU to respond. The perlocutionary act stated is statement of disagreement. He argues that what JW conducted for people with disabilities's walfare is not quite enough. Eventually, they mostly use contrary statement when responding to a case and expressing arguments in debate. 
On the other hand, this study reveals the results, which was different from previous studies. The previous study of perlocutionary acts, researchers focused on perlocutionary acts in a novel and learning process, the results are expressive acts like feeling pleased, sad, apology, exciting (Fitriani, 2017; Sabardila, 2016). The different findings regarding perlocutionary acts between this research and the previous one are the types of perlocutionary acts found that are mostly opposition meanings and governmental terms since the subject of analysis is different. The different findings are also pointed that they did not employ euphemism in the analysis. Other studies in debate focused on illocutionary speech acts show the results that is commissive speech acts like promising and vowing (Juwita, 2017; Andrasari, 2016). However, Agustina \& Bahrani (2016) and Citraresmana (2019) who are using debate as subject analysis apply semantic approach and debate theory.

Surprisingly the result of this study shows that candidates expressing perlocutionary acts are also in euphemistic way. It is because euphemism can be a strategy to express an idea in polite way even though the actual meaning is negative specifically in the political realm. However, politicians often use vague meaning to hide a taboo reality or to conceal self-negative image. The findings show that perlocutionary acts are expressed in euphemistic ways i.e. expression of exaggeration, using loan word, metaphor, understatement and shield. Expressions of exaggeration such as "most problem, the biggest problem" which tends to exaggerate statements that considered excessive. However, it can be hide taboo meaning for it has not clearly demonstrated actual meaning. The next expressions are English loan word such as "revision, disability and difable." Those expressions can be euphemistic way to substitute unpleasant meanings be sounding polite. Another expression is Indonesian metaphor like "authority is biased" that can replace unpleasant meaning. The expression such as "simplify a thing" is also can be a device of euphemism that is understating speech in order to hide taboo meaning. Further, the expressions such as "I think, might, maybe" are also euphemistic device as a shield to protect being offensive.

In addition, this study demonstrated different view from the previous studies regarding euphemism. The previous studies conducted by Sulistyono (2016) and Astuti (2016) are focused on classifying the types of euphemisms and their functions but they did not include analysis of the perlocutionary act. Dealings with a role of euphemism in politics, this study has rather a similar discussion to the previous one. Such as the studies conducted by Fernandez (2014), Samoškaitè (2011), Arif, (2015) in which they focused on the political realm. In their studies, euphemisms have a role to state negative meaning in polite way, it was as the same as this study in which candidates stating refusal in euphemistic way. Besides the distinction lies on the words choice and language data, they did not also include perlocutionary acts in the analysis. However, this study shows that candidates mostly used rebuttal terms that are having opposite meaning to the speaker's idea. It can be seen from the findings indicating the statement of refusal are more often stated than that of acceptance. 
This current study has demonstrated this research has different findings, ways, and elaborations of analysis to the previous one. Hence, this study can enhance an insight related to the study of euphemism elaborated with perlocutionary acts in political debate. Further research can be carried out by applying another relevant theory to study on Presidential debate.

\section{CONCLUSION}

The whole study has pointed out that the use of euphemism can create an effect to other debaters in presidential debate 2019. Effects or perlocutionary acts are both acceptance and refusal. The perlocutionary act of refusal is occurred frequently than that of acceptance. The perlocutionary act of refusal is mostly containing opposition in meanings; it it presents that candidates have opposite view and thought. Since debate is intended to catch opinions from candidates to find solution related to a case, candidates convey different argument based on their own opinion and reinforce their ideologies. On the other hand, perlocutionary acts are expressed involving euphemism, it assumed that candidates intended to show their self-positive image and hide unpleasant reality by stating argument in polite way.

\section{REFERENCES}

Agustina \& Bahrani. (2016). The implementation of British parliamentary debating in Mulawarman debate society. Indonesian Journal of EFL and Linguistics , 79-97. Vol. 1 No. 1, 2016. DOI:http://dx.doi.org/10.21462/ijefll.vlil.6

Allan, K., \& Burridge, K. (1991 ). Euphemism \& Dysphemism: Language used as Shield and Weapon. New York: Cambridge University Press.

Andrasari, L. (2017). Tindak tutur Komisif Dalam Debat Pilkada Kabupaten Sambas Tahun 2015. Jurnal Pendidikan dan Pembelajaran Khatulistiwa Vol 6, No 4 .

Arif, N. F. (2015). Social and Cognitive Implications of Using Euphemisms in English. International Journal of English Linguistics; Vol. 5, No. 6 , 151-156.

Astuti, A. (2016). Eufemisme bahasa pendukung Capres RI dalam akun Facebook:Kajian Sosiopragmatik. Universitas Andalas.

Austin, G. (1962). How To Do Things with words. Massachusetts: Harvad University Press Cambridge.

Brown, P. a. (1987). Politeness: Some universals in language usage. Cambridge: Cambridge University Press.

Burridge, K. (2012:76). Euphemism and Language Change: The Sixth and. Journal in English Lexicology, 65-92.

Burridge, K., \& Allan, K. (2003). Taboo and the Censoring of language. New York: Cmabridge University Press.

Chaer, A. (1995). Sosiolinguistik : Suatu Pengantar.Jakarta : Rineka Cipta.

Citraresmana, E. (2019). Konsep makna kita dan kami dalam debat capres bulan Januari 2019: Kajian Semantik Kognitif melalui studi korpus. Metalingua, Vol. 18 No. 2 , 103-112. 
Crespo Fernández, E. (2005). Euphemistic Strategies In Politeness And Face. Pragmalingüística, .

Dipodjojo, A. (1982 : 59). Komunikasi Lisan. Yogyakarta: P.D Lukman.

Fernandez, C. (2014). Euphemism and political discoursein the British regional press. ResearchGate, DOI: 10.5817/BSE2014-1-1 .

Fitriani. (2017 :53). Analisis tindak tutur dalam novel marwah di ujung bara karya r.h. Fitriadi. Master Bahasa, 51-62.

Indarwati. (2019). Analisis elaboration likehood model dalam kalimat persuasi kampanye presiden 2019. Undas, 176.

Juwita, R. (2017). Tindak Tutur Ekspresif Dan Komisif Dalam Debat Calon. journal Eduscience

Lacone, S. (2003). Write to the Point: How to Communicate in Business With Style and Purpose. The United States of America: Career Press.

Leech, G. (1983). Principle of Pragmatics. London: Longman.

Liska Andrasari, M. A. Tindak Tutur Komisif Dalam Debat Pilkada Kabupaten Sambas Tahun 2015.Program Studi Pendidikan Bahasa Indonesia FKIP Untan, Pontianak.

Mahsun. (2007 : 233). Metodologi Penelitian Bahasa: Tahapan Strategi, Metode, dan Tekninya. Jakarta: Raja Grafindo Persada.

Prayitno, H. k. (2019). Realisasi tindak kesantunan pada komentar akun instagram Jokowi. Kandai .

Searle, J. (1969). Speech Acts. Cambridge University Press.

Saifudin, A. (2019). Teori Tindak Tutur dalam Studi linguistik. LITE, Volume 15.

Samoškaitè, L. (2011). 21st Century Political Euphemism in English Newspaper.Lithuania: Vilnius Pedagogical University.

Sudaryanto. (1993). Metode dan Aneka Teknik Analisis Bahasa (Pengantar Penelitian Wahana Kebudayaan secara Linguistik. Yogyakarta: Duta Wacana University Press.

Sulistyono, Y. (2016 ). Struktur Dan Fungsi Eufemisme Dalam Rubrik Obituari Harian Kompas. LEKSEMA , 73-80.

Wiyanto, A. (2003). Debat Sebagai Retorika. Jakarta: Aneka Ilmu.

Yule, G. (1996). Pragmatics. New York: Oxford University Pers. 